\title{
UESTIONS OF TRANSNATIONAL CINEMA: THE BALTIC CASE FROM CULTURE TO BRANDING
}

\section{Giuseppe Raudino}

Hanze University of Applied Sciences, Groningen, Email: g.raudino@pl.hanze.nl

\begin{abstract}
:
Although Baltic Cinema is nowadays acclaimed as an industry full of great potential, its international success is still dependent on - and limited by - some factors that are worth being explored. It is undeniable that huge efforts have been made in the past years with regards of cooperation beyond the national borders of the involved countries, promoting transnational productions, festivals and debates; though, it seems that Baltic Cinema as a unity, model, or even genre, is not yet achieved.

The paper aims to explore - starting from the cultural, economic and political diversity of the players - the reasons why the works produced within this area are not always perceived as parts of the same cinematographic paradigm. In fact, the idea of Baltic Cinema as a whole clashes with a plethora of different interpretations and perspectives, so that it is possible to distinguish in the first place between narrow and broad acceptations of the adjective Baltic and the geographical range it stands for. Furthermore, the paper presents a reflection on some concepts and common habits typical of the mainstream cinema industry, such as product placement, synergy, crossmedia entertainment, in relation to their presence in the Baltic film production (or the lack thereof).

The ultimate goal of the paper is to provide the reader with some elements that might be useful to characterize, (re)define and come up with a preliminary idea about Baltic Cinema as a profitable, internationally appealing and unique brand.
\end{abstract}

\section{Rezumat:}

Deși Cinematografia Baltică este actualmente ovaționată ca o industrie cu un potențial insemnat, succesul său internațional este încă dependent și limitat de câțiva factori care merită să fie explorați. Este de netăgăduit faptul că au fost depuse eforturi uriașe în ultimii ani in vederea cooperării transfrontaliere, prin promovarea producțiilor, festivalurilor și dezbaterilor transnaționale; totuși, s-ar părea că nu s-a ajuns la o Cinematografie Baltică ca o unitate, un model și chiar ca un gen.

Această lucrare urmărește să exploreze - pornind de la diversitatea culturală, economică și politică a actorilor - motivele pentru care creațiile realizate în acest domeniu nu sunt întotdeauna percepute ca fiind parte componentă a aceleiași paradigme cinematografice. De fapt, întreaga idee a Cinematografiei Baltice se află în raport de antinomie cu pletora de interpretări și perspective diferite, așa că este 
104 | Revista Română de Studii Baltice și Nordice/The Romanian Journal for Baltic and Nordic Studies 7(2) necesar să distingem, în primă instanță, între interpretarea îngustă sau mai largă a adjectivului Baltic și dimensiunea geografică pe care o definește. In plus, lucrarea prezintă o reflecție asupra câtorva concepte și deprinderi tipice curentelor principale ale industriei cinematografice, precum plasarea produsului, sinergia, divertismentul cross-media în relație cu producția de film Baltică (sau absența acesteia).

Scopul final al lucrării este de a oferi cititorului câteva elemente care ar putea fi utile pentru a caracteriza, (re)defini și veni cu o idee preliminară despre Cinematografia Baltică ca un brand profitabil, atrăgător pe plan internațional și unic.

Keywords: Transnationalism, regionalism, branding, transnational cinema, Baltic cinema, Global cinema, regional cinema

\section{Baltic Cinema and Transnationalism}

A study of Baltic Cinema is only possible if conceived within the framework of transnationalism.

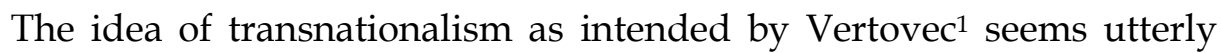
linked to globalization, since it is a phenomenon that begins with the diaspora of a community who identifies, compares and blends their own identity in relation to the culture of the new country, interweaving economic relations and engaging in political activities to such a degree that even the place (or locality, to use Vertovec's terminology) needs to be reconstructed.

From this perspective it is clear how the so-called globalization is accelerating the process of virtually any transnationalism: the widespread popularity of the internet, the simplicity of making overseas money transactions, the possibility of travelling at affordable prices with low fares airlines, the opportunity offered by the social media to discuss politics and redefine localities in the cyberspace... all these elements suggest that today transnationalism is stronger, more effective and more present than ever. Especially if referred to the European Union, the free movement of capitals, goods and workers has lately determined consistent migratory flows between member countries and consequently an increase of transnationalism-related phenomena.

Baltic cinema as a study unit is something that obviously goes beyond the national borders of those countries that belong to a specific area or region. This is definitely in line with what Iordanova ${ }^{2}$ observed with regards to

\footnotetext{
1 S. Vertovec, 'Conceiving and researching transnationalism'. Ethnic and racial studies 22 (2, 1999): 447-462.

2 D. Iordanova, Cinema of the other Europe: the industry and artistry of East Central European film (London, New York: Wallflower Press, 2003), 12.
} 

cinema about "regional cycles and regionalism". In this case the concept of regionalism must be intended as a form of transnationalism in opposition to nationalism. The reason why a transnationalism-based study approach is important can be found in the opportunity of discovering "leading stylistic or narrative trends and other general aspects [...] that otherwise [within a national framework] remain neglected"3. Moreover, we can add another important aspect: by addressing the study of cinema transnationally, we can also identify new potential markets and more profitable business opportunities for different players in the industry, such as producers, investors, distributors and exhibitors.

\section{The presence of Baltic Cinema on the internet}

Before we take on the definition of "Baltic cinema", in order to orientate ourselves it is worth looking up on Google how many occurrences we can find after we type some relevant key words related to some transnational cinemas. We do not mean to carry out any scientific experiment but, given that a search engine like Google indexes thoroughly a huge number of websites categorized with specific contents worldwide, we can gain a general picture about the popularity of our topic over the internet and compare it with other regional cinemas.

Besides Baltic Cinema we chose some adjectives that denote other cinema frameworks, like Balkan, Scandinavian, Mediterranean and so forth. Each adjective has been followed by the word cinema and the exact phrase has been searched on Google.com in December 2013. For the sake of completeness we must point out that the number of the occurrences is estimated and can vary if a deeper search is triggered, which usually happens when the same key words or key phrases are used in combination with other Boolean operators 4 . However it should be acknowledged that our searches have been carried out at an acceptably constant level of depth and therefore we assume that the numbers are consequent and mutually comparable even though they might differ from the actual numbers.

\footnotetext{
${ }^{3}$ Ibid.

${ }^{4}$ Google Webmasters [Googlewebmasterhelp]. How precise is the number of results in a site: query? [video file]. Retrieved from http://www.youtube.com/watch?v=2ix3mHeL7hg, September 21, 2010.
} 


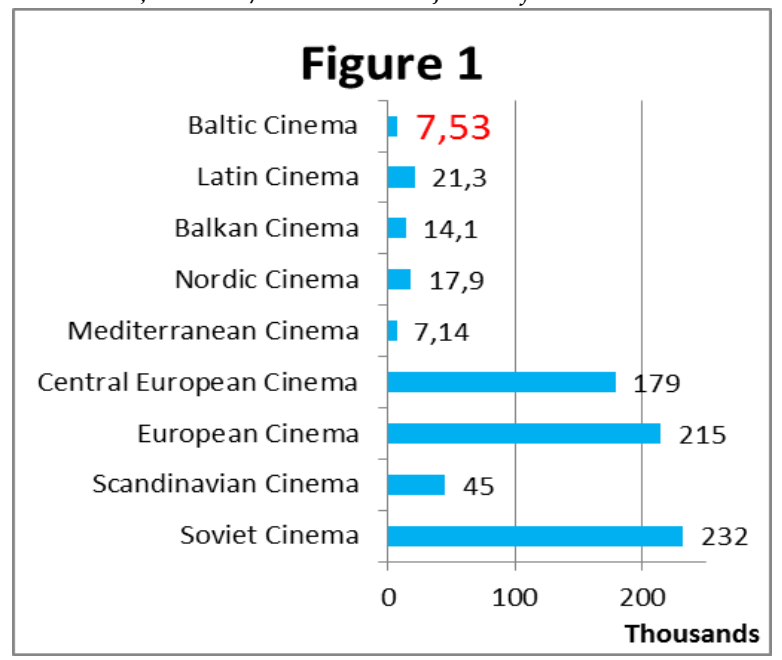

In figure 1 we can see that Soviet Cinema returns the highest number of occurrences, followed by European Cinema and Central European Cinema. Scandinavian Cinema, with 45.000 occurrences has the biggest online presence among the minor cinema landscapes. Baltic Cinema, with 7530 occurrences, ranks one of the lowest, meaning that it is 6 times less popular than the Scandinavian Cinema and almost 30 times less than the European Cinema.

The same procedure has been repeated on Google Scholar, which is a bibliographic database with scholarly literature, to have an overview on the academic interests and publications.

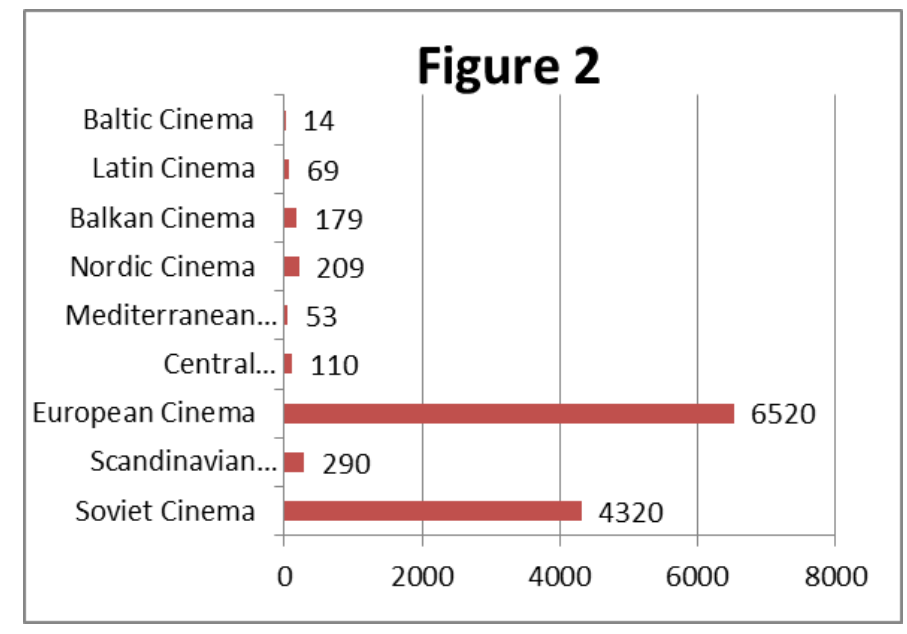

It is clear Baltic cinema, according to our findings, is the least common topic among academics, but even on other more popular databases this topic 
looks underrepresented. On Wikipedia, for instance, at the time of this writing, there is no specific entry for "Baltic cinema" (unlike "European cinema") although a rather vaguely specified "Baltic cinema task force" ${ }^{5}$ had been already created some five years ago.

The popularity of Baltic cinema remains somewhat low also in the specialized e-magazines, websites and blogs. No dedicated sections can be found on magazines like Cineaste, Film Criticism and Film International.

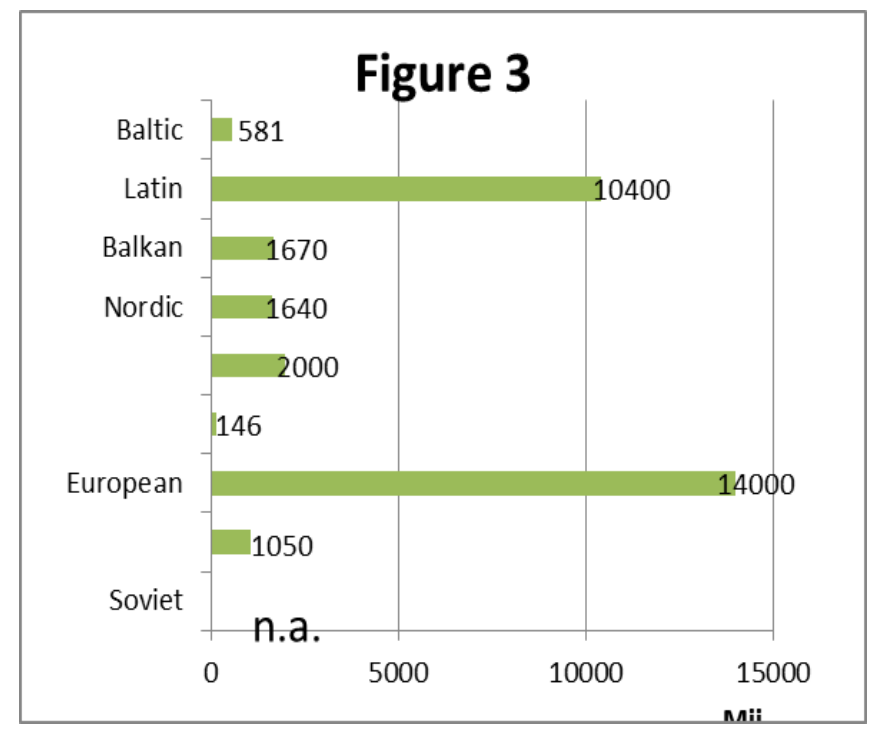

An interesting area, which is worth exploring too, is related to the flourishing number of film festivals in the Baltic area. The presence of a certain number of festivals in the Baltic region has been pointed out by Niskanen, Kakeo, Petkovic and Severns 6 . Once again, we repeated the same procedure to know the estimated number of occurrences returned by Google. This time the key terms were adjectives representing the regional area (Baltic, Scandinavian, etc.) each time singularly combined with the exact phrase "film festival". By doing so we aimed to identify the webpages containing both the regional reference and the unique expression "film festival", excluding as a consequence all the webpages containing just a reference to a regional movie

5 Baltic cinema task force. In Wikipedia. Retrieved from http://en.wikipedia.org/w/index.php?title=Wikipedia:WikiProject_Film/Baltic_cinema_task_ force\&oldid $=236400137,2008$.

${ }_{6}^{6}$ E. Niskanen, Y. Kakeo, S. Petkovic, and K. Severns, Japanese: Baltic Sea Region film co-production; Japanese views, No. 1228. ETLA discussion paper, 2010, 102. 
108 | Revista Română de Studii Baltice și Nordice/The Romanian Journal for Baltic and Nordic Studies 7(2)

or to another type of festivals (e.g. Baltic music festival, Mediterranean food festival, Scandinavian culture festival and so forth were automatically excluded in our search).

Figure 3 shows that European Film Festivals and Latin Film Festivals are the most popular occurrences (above 10 million entries each), followed by the Mediterranean Film Festivals. For obvious reasons, Soviet Film Festivals is not applicable as a search term, although Google returned automatically the results for Russian Film Festivals instead. We decided not to consider Russian festivals because Russia is a nation and, therefore, its consideration goes beyond the focus of this paper on transnationalism and/or regionalism.

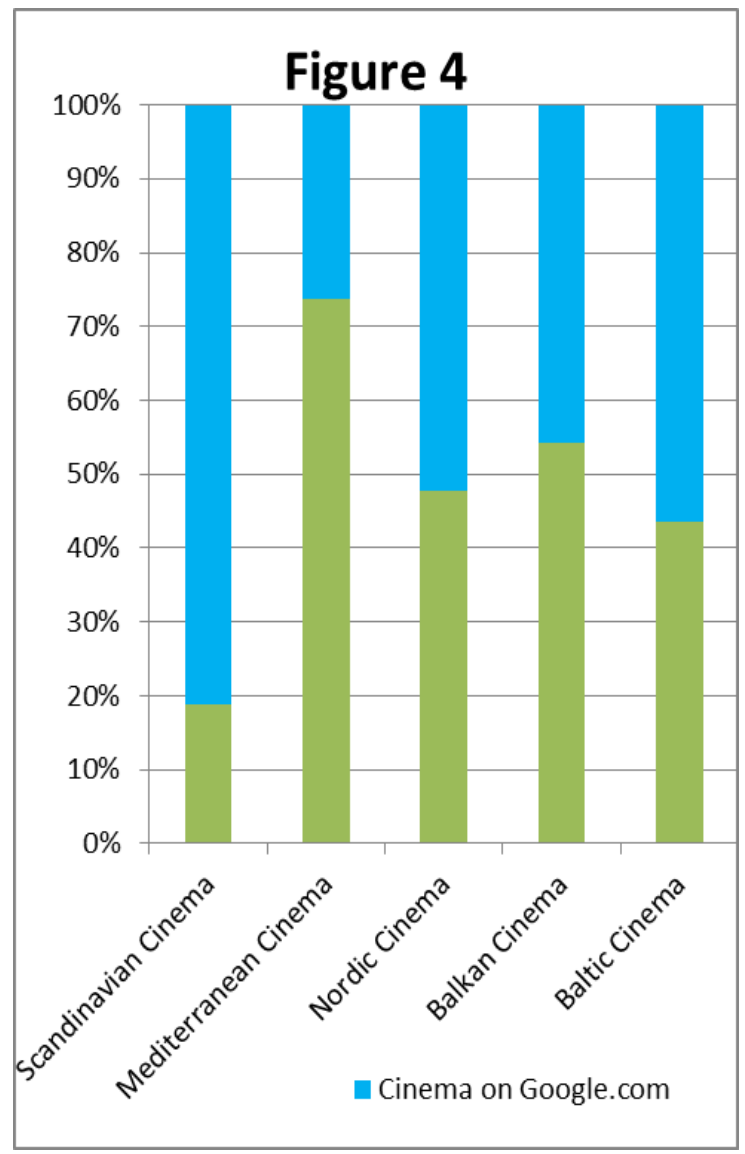

It is quite interesting to find the ratio between the online presence of a specific regional cinema and the film festivals related to the relevant region. As a matter of fact, this ratio might suggest how the popularity of a given regional cinema is due to this kind of events. 
In figure 4 , which is an elaboration on figure 3 and figure 1 , we combined together the estimated results for the regional cinemas and the estimated occurrences for the relevant festivals. The five columns represent a selection of the regional cinemas addressed thus far. We decided to limit the range to these five after we have excluded Soviet cinema (it doesn't make sense to talk about Soviet film festivals after 1991), Central European cinema (due to the substantial lack of festivals) and both Latin and European cinemas, whose preponderant online presence makes pointless any comparison with the other emerging cinemas.

What stands out from the graph is that Scandinavian cinema and Mediterranean cinema are opposite to each other. The former can rely on a solid presence online despite the relative number of festivals is rather low in comparison to the webpages, blog entries and whatever is published online according to Google's results; the latter, instead, seems to owe most of its popularity to the festivals that somehow promote the Mediterranean culture.

With regards to the Baltic cinema, the situation appears balanced, although the absolute numbers are not very high as we have seen before. Incidentally, the occurrences of Baltic cinema on Google.com are certainly comparable to those obtained with the Mediterranean cinema, and Figure 5 shows this comparison more clearly.

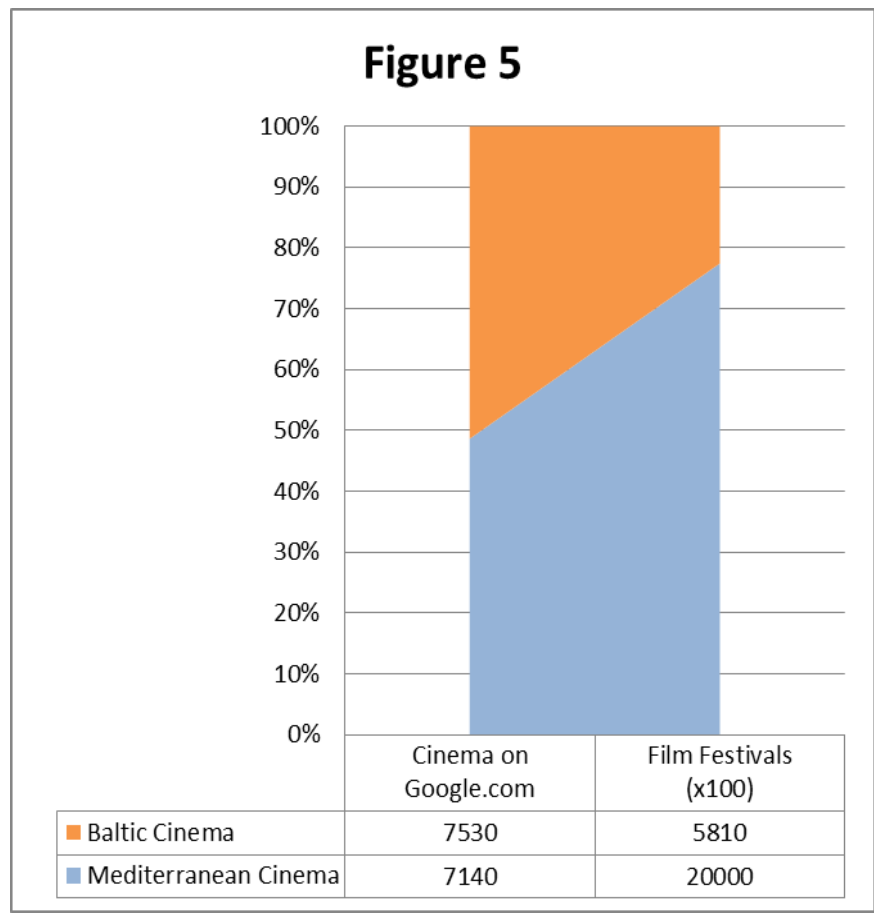




\section{Ambiguities of a newborn paradigm}

So far we know that Baltic cinema should be considered a transnational phenomenon that is just in the initial process of coming to the attention of some international audiences. Precisely because it is a rather new object of study, we can still find several definitions that are at times extremely diverse or even contradictory.

There are some authors like Ingvoldstad who would limit Baltic cinema to the Latvian, Lithuanian and Estonian cinemas, detached from the Soviet heritage and studied as a whole after a better understanding of their own national characteristics7. This categorization is thoroughly in line with what Iordanova ${ }^{8}$ was postulating and envisaging when she reflected on the "vacuum" left by the post-Communist era and the need to study the cinemas of Latvia, Estonia and Lithuania in their togetherness. The Baltic Countries are also the main focus of Harry Weeks' analysis, which is one of those few studies that concretely address the aspect of transnationalism in the Baltic region in terms of common trends (Baltic as transitional cinema) and common stylistic choices, like the considerable preference for the documentary9.

In opposition to the above-mentioned studies, there is also another tendency - slightly less academic and more business-oriented - to define the Baltic cinema with a broader scope. It is the case of the Baltic Metropoles (also known as BaltMet), a consortium of prominent municipalities and capitals close to the Baltic Sea. The Baltic Metropoles, within the project named BaltMet Promo, have recently commissioned a couple of studies ${ }^{10}$ about the feasibility of Japanese/Baltic film coproduction. The researches were carried out respectively by the Research Institute of Finnish Economy ETLA (Elinkeinoelämän tutkimuslaitos) and Aalto University. Both studies considered the Baltic Cinema film production in a wider sense, consisting of "Denmark, Estonia, Finland, Germany, Latvia, Lithuania, Norway, Poland, Sweden and the Baltic Sea region of Russia"11.

\footnotetext{
7 B. Ingvoldstad, 'The Paradox of Lithuanian National Cinema.' Via Transversa: Lost Cinema of the Former Eastern Bloc, Place and Location: Studies in Environmental Aesthetics and Semiotics 7 (2008), 152.

8 Iordanova 2003, 14.

${ }^{9} \mathrm{H}$. Weeks, 'Re-cognizing the post-Soviet condition: the documentary turn in contemporary art in the Baltic States'. Studies in Eastern European Cinema, $1(1,2010)$.

10 Niskanen at al. 2010; M. Paajanen, O. Kupi, A. Panfilo, and J. Urmas, 'International film cooperation inside the Baltic Sea Region and with Japan'. Aalto University Publication Series Business + Economy, 13, 2011.

11 Niskanen at al. 2010, 1; see also Paajanen at al. 2011, 4.
} 
The first trend we can notice is that there are two major approaches toward Baltic cinema: on one hand we have a restricted view, mostly supported by academics, that relates Baltic cinema only to the post-communist cinema production of the Baltic States; on the other hand there is a broader concept of Baltic cinema, mainly supported by political and economic institutions, that considers the label "Baltic" applicable to any film whose production process involves one of the countries touched by the Baltic Sea, from Sweden to Finland, from Denmark to Russia.

It is undeniable that all the countries across the Baltic Sea share a long history of cooperation, which dates back to the late Middle Ages up to the early Modern Period thanks to the Hanseatic League, but in our opinion countries like Sweden and Germany can be hardly included in a Baltic cinema paradigm, unless some specific criteria, which will be discussed later, are met.

Sweden, for instance, is the biggest country within the Scandinavian Peninsula in terms of total area, population and gross domestic product (Sweden, 2013): how is it possible to consider its cinema Baltic rather than Scandinavian? It does not come as a surprise that several scholars are against this conflation of Swedish and Baltic cinema12, especially when it comes to comparing their last century's developments. Referring to Sweden and Latvia - but it is also true for any other Baltic republic - Louis Menashe wrote: "[They are] neighbors across the Baltic Sea, but worlds apart in the modern historical development. [...] [They] both share affection for film, and boast some strong film traditions." 13 Menashe referred to strong film traditions, but he didn't write common film traditions; instead, he underlined the differences and the contrast and "the serious fiscal divide separating Western- and Eastern-European film Establishments"14.

Something vaguely similar can be argued whenever German cinema is matched to Baltic cinema. The fact that parts of the coastlines of both countries lie on the Baltic Sea does not imply any stylistic or industrial closeness of their respective national cinemas. The role played by this medium for the German nation, from the origin to the Neuer Deutscher Film, passing through the Nazi propaganda, can be hardly assimilated to the Baltic culture, even when German filmmakers choose the Baltic Sea as a location or theme for their works. Most of the time "the depiction of the Baltic Sea [...] in German film[s]

\footnotetext{
12 Ingvoldstad 2008, 151.

${ }^{13}$ L. Menashe, 'Border crossings in the Baltic: The "Transit Zero" Film Conference'. Cinéaste 26 $(3,2010): 62$.

14 Ibid., 63.
} 
evoke[s] [...] images of boundless space, room for expansion, freedom and new beginnings" 15 .

Ludewig (2003) also pointed out that, particularly in the post-Wall German film production, the Baltic Sea is presented as well as the symbol for a mystic union with the past, when there was no Iron Curtain to divide the country. Thus the Baltic Sea in the recent German films can be highly selfreferential and strongly reminiscent of Germany's history, rather than a mere example of transnationalism. However, it is worth exploring in the next paragraph wheter the nostalgia for, and the regression to, the past could be considered recurring motifs in the Baltic cinema in general, especially if we consider the analogies with the Estonian cinema of the 1960s, for which the Baltic seaside "function[ed] as illusionary 'ideal landscapes' [...] to re-assure a certain continuity of the ideologically charged notion of homeland and the sustainability of the (local/national) identities connected to it" 16 .

\section{Oppositional definition of Baltic cinema}

We think that the definition of Baltic cinema must go beyond some lists of countries and has to dig deeper in the direction of themes, genres and cultures. Let's take as an example the case of Barta's Freedom, a Lithuanian film coproduced with France and Portugal and shot in the Northern Africa. Does the nationality of the author make the geographical reference of the product? Ingvoldstad gives and indirect answer by reporting the general mood of the audience and their expectations, which was quite disappointed in Lithuania and enthusiastic abroad, but he also addresses another fundamental issue: on one hand the paradigm of national cinemas in shifting towards transnationalism; on the other hand - translating his thoughts from a national to a transnational level - the nationality of the director or the area where a film is produced doesn't make it automatically eligible for a specific regional classification such as Baltic ${ }^{17}$.

As we just mentioned above, our focus should rather be on themes, genres and cultures, with an eye on production processes. Iordanova already observed that what makes regional a specific cinema is not only the geopolitical aspect but also similar industry structures, as well as shared

\footnotetext{
15 A. Ludewig, 'Screening the Beach-Probing the Past: The Baltic Sea in Contemporary German Cinema'. Landscapes: the Journal of the International Centre for Landscape and Language 2 (3, 2013): 9. 16 E. Näripea, 'Nature, Movement, Liminality: Representing the Space of the Nation in 1960's Estonian Cinema'. Regioninés Studijos, $(5,2010)$ : 100.

17 Ingvoldstad 2008, 140-142
} 
concerns/stories and, last but not least, a consistent style, which includes camera movements, photography and other cinematic techniques ${ }^{18}$.

Before we make an attempt to inventory the common features that some national cinemas around the Baltic Sea might have in common, it is advisable to begin with a more general definition based on oppositions.

The main regional cinemas close to the Baltic cinema for historical, geopolitical and cultural reasons are: Scandinavian, Soviet, European in general and Central European in particular. To complete the picture, we also decided to consider the American cinema (Hollywood) and compare features and trends of Baltic Cinema to a Globalized arena.

Scandinavian cinema seems very strong in supporting the so called cultural diversity model ${ }^{19}$ while the crime fiction is knowing nowadays a huge popularity in Scandinavian, also thanks to a vivid production of literary works from which cinema gets inspired. Another area that distinguishes Scandinavian films is the representation of sexuality, from the happy porn of the Seventies, consisting of "simple narratives framed by nudity and explicit allusions [...] [that] became established as a Danish genre, if not as Danish cinema altogether" 20 , to many sexually explicit films lately produced by the Danish Zentropa. Understandably the Scandinavian countries have been influenced by the Danish policy against film censorship since 1969, and this has led to an early exploration of themes like eroticism in their cinemas, but we must admit that sexuality is not neglected in recent productions around the Baltic area such as the Finnish Frozen Land (2005) and Purge (2012) or the Estonian Autumn Ball (2007).

Soviet cinema is opposite to Baltic cinema possibly in a stronger way than the Scandinavian, and this is true especially for the Baltic States, which have suffered from an uncomfortable coexistence with the Soviet culture. The impositions made by Moscow during the Communist rule and its attempts to cancel any culture other than the Russian in favor of the latter were unbearable, that's why any notion of Baltic cinema is incompatible with Soviet Cinema, regardless of whether we are referring to cinematic traditions of former Soviet republics, countries outside the influence of the USSR or both. As we wrote before, Baltic cinema can be understood only detached and

\footnotetext{
18 Iordanova 2003, 14.

19 I. Bondebjerg, and E.N. Redvall, A Small Region in a Global World. Patterns in Scandinavian Film and TV Culture (Centre for Modern European Studies - CEMES, University of Copenhagen, 2011), 18.

${ }^{20}$ L. Wallenberg, "Bedroom Mazurka," in The cinema of Scandinavia, ed. T. Soila (London, New York, Wallflower Press, 2005), 168.
} 
"disaggregated from Soviet cinema" 21 or by "de-flattening [...] the post-Soviet condition"22, whose central power has always tried to keep down minorities and sub-communities spread in the periphery of the empire. This is the reason why identity is one of the primary topics within Baltic cinema and why Baltic cinema defines itself (also) in opposition to the Soviet tradition, always quite busy with propaganda and a self-celebratory nationalism that has never left any space for other nations and ethnic groups.

Furthermore nostalgia and regression to the past are two themes that can be linked with the hate towards the Russian rule: what happened in Germany's cinema, as explained in the previous paragraph, might be also applicable to Estonia, Latvia and Lithuania. In this case, though, the nostalgia for the past refers to long-awaited and short-lasting independence time, which was gained by the three Baltic republics between the two World Wars, or even to a faraway glorious past of freedom and independence, like the one depicted in Kaer's Men at Arms (2005), an Estonian film set in the Thirteenth century during the Livonian Crusade. In Men at Arms, as noted by Ewa Mazierska, it is present an exaggeration of national stereotypes for humorous purposes, while the issue of different identities within the Estonian society is presented with a surprisingly great sensitivity in terms of cultural diversity, "not [like] a homogenous nation, but a collection of different ethnic groups, each speaking a different dialect and enjoying its own way of life" 23 . The past in the Baltic cinema could therefore be the ideal and idealized situation preceding any foreign rule, when an identity made of different identities was neither offended nor humiliated by external forces.

Less oppositional, but still with several core differences if compared to the Baltic cinema, is the European and, under certain aspects, the Central European cinema. The World War II first, and Cold War later, have played a big role in diversifying themes and focuses. For instance, let's think about the innumerous European films about the Holocaust, or how often the postwar reconstruction has been represented by European screenplay writers and film directors. Mixed feelings like fear for the uncertainty and hope for the future, along with the influence of the existentialism coming from the philosophy, converged into solid movements that have left a mark in the history of cinema, like the Italian Neorealism or the French New Wave. Even the works produced by Polish Film School, with the aim of contrasting the socialist

\footnotetext{
21 Ingvoldstad 2008, 152.

22 Weeks 2010, 60.

${ }^{23}$ E. Mazierska, 'Post-communist Estonian Cinema as Transnational Cinema,' Kinokultura 10, Retrieved from http://www.kinokultura.com/specials/10/mazierska.shtml, 2010.
} 
realism, "represented early attempts to recast the recent past in a more (artistically) honest, less ideological light"24, while the Central European cinema in general was "mostly preoccupied with investigation of morality, of the relationship between the individual and social and historical processes" 25 (our emphasis). We believe that these processes have been elaborated by the European cinema with a steady reference to the huge cultural heritage Europe is built upon: would, for instance, La Dolce Vita (1960) be ever thinkable without the beauty of Rome in the background? And how about the ravishing countryside of France 26 and Stonehenge in Polanski's Tess (1979)?

Finally, Hollywood as Globalized American cinema, can be considered a touchstone for the identification process of Baltic cinema.

We can first point out that in the Globalized cinema "plots [are] chosen for cultural 'vagueness' or openness, so as to appeal to as broad a market as possible" 27 . This means that its content tries to get across an overall universal message, possibly with a strong emphasis on stereotypical and easy-tounderstand situations, facts, characters. On the contrary, Baltic cinema seeks a different level of engagement and interpretative efforts with the viewer, since context, economic factors, historical background, cultural customs and geopolitical figures about the Baltic region cannot be taken for granted as easily as the American values imposed worldwide by the strength of the US financial power. Incidentally, from a financial point of view, Schiller ${ }^{28}$ noted how US entertainment industry giants can afford to lower the price and adapt to the local markets around the worlds with an extreme ease, erasing any competition with local productions thanks to their unfairly cheap but high technical quality products, sometimes made with an impressive use of cutting edge technological means and surprising special effects in post-production.

The aggressive market-oriented approach typical of the Global cinema is supposedly paid back with the successful and widespread promotion of the US values - such as capitalism, the American dream, democracy, the United States as a global political and military leader - and their branded goods

\footnotetext{
24 Anessi, T. 'Moving Ahead into the Past: Historical Contexts in Recent Polish Cinema'. IMAGES The International Journal of European Film, Performing Arts and Audiovisual Communication XI (20, 2012): 7.

25 Iordanova 2003, 13.

${ }^{26}$ see H. Kennedy, 'Tess - Polanski in Hardy Country'. American Film (October issue, 1979), 6269.

27 G. Branston, and R. Stafford, The media student's book, $4^{\text {th }}$ edition (New York: Routledge, 2006), 490.

${ }^{28}$ H. I. Schiller, 'Not yet the Post-Imperialist Era,' in The Media Studies Reader, eds. T. O'Sullivan, \& Y. Jewkes (London; New York: Arnold, 1997) as cited in Branston and Stafford 2010, 145.
} 

which appear in the movies (the so called product placement), allegedly promoting consumerism and brand loyalty.

\section{Common features and common ground}

After we have seen what Baltic cinema is not, it is worth reflecting about the main features of Baltic cinema.

Weeks ${ }^{29}$ observed that national cinemas in the Baltic countries have adopted more frequently the aesthetics and the formal structure that usually belong to the documentary. This would be in line with the pedagogical engagement that nowadays still more numerous filmmakers around the world are supposedly trying to establish with the viewer according to Week, although Ingvoldstad had already suggested that the documentary turn was probably due to financial problems after the collapse of the Soviet Union rather than a conscious aesthetic choice, for documentaries were easily funded by the European Union ${ }^{30}$. At any rate, we strongly agree with Weeks' analysis at the point when he refers to "a generation in a transitional situation" 31 . Baltic cinema is a generational and transitional cinema, at least in the moment we started exploring it. Perhaps in twenty years it won't be any longer influenced by these two aspects, but the process and the efforts in re-building a new society after such a long Soviet rule is still visible in the socio-economic and political struggles that still affect the Baltics and, as a consequence, the nearby surroundings too.

Nevertheless, change and transition thanks to the new generations is not only reflected in the cinema. A generational ferment was registered for example in 2003, when Skype was launched. Mainly designed by three Estonian programmers, the project benefitted by Danish and Swedish contributions, and this successful ICT project became a sign for the vivacity of a transnational Baltic enterprise. This cultural growth can be traced in the education too: in fact it does not look like a coincidence that $40 \%$ of Estonians aged between 30 and 34 have completed their tertiary education, showing a rather high percentage if compared to many other European members 32 .

However, the enthusiasm of a new generation artists, who found itself between the memory of bad life conditions and the promise of a bright future, might turn into a biased or altered cinematic representation of their own

\footnotetext{
${ }^{29}$ Weeks 2010, 59, 63

30 Ingvoldstad 2008, 150.

31 Weeks 2010, 67.

32 OECD. Education at a Glance 2013: OECD Indicators, OECD Publishing, 2013, 39.
} 

environment, especially when they try to build a good image at all costs, in the attempt to convince an international audience that the Baltics are after all "a beautiful place with European values [...] - an average, nice looking, reasonably wealthy European setting without a trace of anything postSoviet" 33 . On the contrary, when they don't have this precise purpose, some films use to "make the surroundings and the natives appear depressing to the point of being grotesque [...while the area is] a bleak, frightening place far away from the safe, reasonable Europe" 34 .

Although it is understandable that any grotesque representation of the reality will be unconditionally despised by its inhabitants, it is important to bear in mind that it might become essential in the perception of Baltic cinema among international viewers, especially if it is a grotesque and exaggerated representation of gloomy atmospheres, dark feelings, profound solitudes, coldness, ineffable sensibilities, depression and despair.

\section{Figure 6}

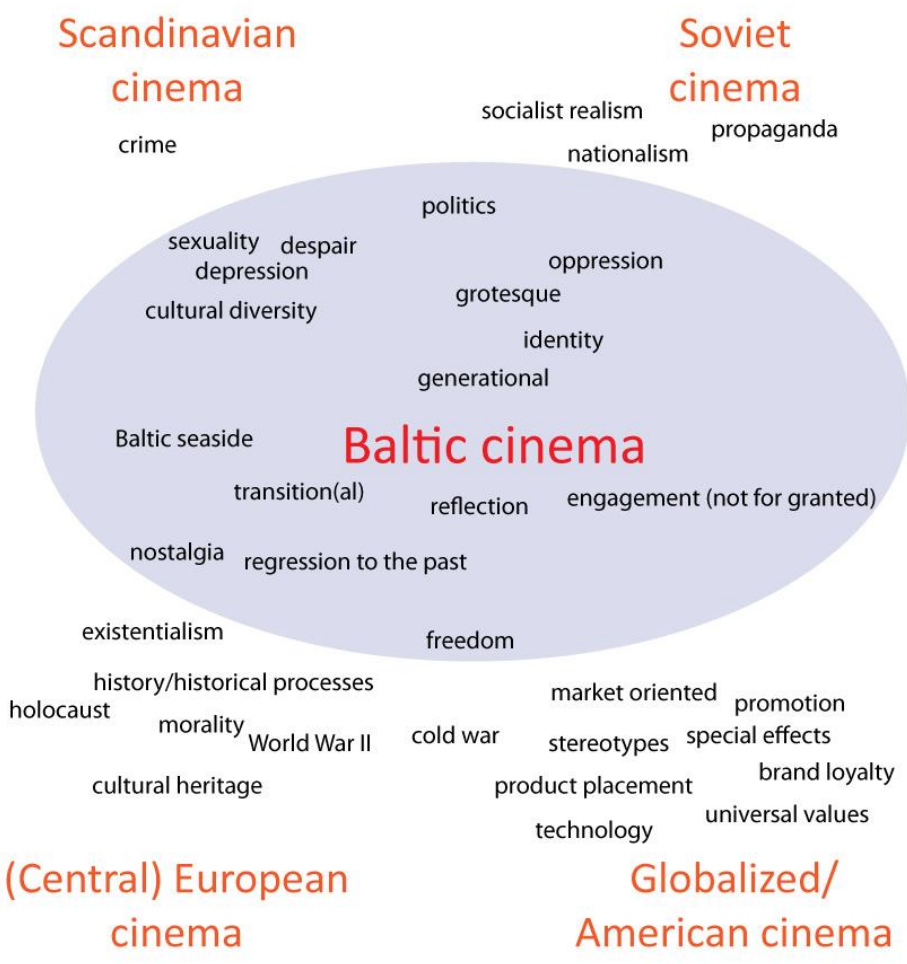

\footnotetext{
33 M. Laaniste, 'Conflicting Visions: Estonia and Estonians as Presented in the Cinema of the 1990s and 2000s'. Studies on Art and Architecture, 20 (3-4, 2011): 140.

34 Ibid., 143.
} 
Figure 6 shows Baltic cinema in opposition to other regional cinemas thus far mentioned. All the key elements that have been discussed above are spread over the graph topologically, according to the supposed closeness or the farness to a given paradigm. The distance between two or more elements cannot be based upon objective measurements but it is established instead by a qualitative impression based on the analysis contained in the previous paragraph, where every single key concept was highlighted in bold.

Despite it is rooted in a specific region, we think that Baltic cinema cannot be defined only by geographical references or by the nationality of their authors/producers/actors. On the contrary, we think that the essence of Baltic cinema can be found in a series of themes, topics and stylistic choices that should appear in every film that is considered part of this cinematic paradigm.

The ellipse defines the imaginary area that encompasses the most relevant elements one could expect to find in the Baltic cinema. Moreover, that elliptical line and what it encloses will be the starting point for us to develop a proposal about Baltic cinema as a brand in the following paragraphs.

\section{Baltic cinema as a profitable brand}

The idea that branding can be applied to public institutions, and not only to commercial goods, is rather recent. The ultimate goal of any brand activity is obviously the profit achieved by sales, subscriptions or the contribution from new investors, but the economic success is generally the consequence of a positive and widespread association between the product and its qualities.

Generally speaking, every brand is a combination of name, identity and reputation of a specific product, service or organization (Anholt, 2006: 4). ${ }^{35}$ Furthermore, every brand is supposed to have a so-called unique selling proposition, which is a specific quality that is communicated to potential buyers or investors ${ }^{36}$.

Anholt has even conceptualized a branding activity, which he renamed as competitive identity, that is designed to enhance some aspects of an entire region $^{37}$. Although our focus is not on the promotion of a geographical area

35 S. Anholt, Competitive identity: The new brand management for nations, cities and regions (Basingstoke [England]: Palgrave, Macmillan, 2006), 4

36 Branston and Stafford 2006, 304

37 Anholt. 
but the promotion of a cinema that is under certain aspects linked to it, Anholt's perspective supports our belief that a regional/transnational cinema can become the object of a branding activity.

Despite he was referring to the national Irish cinema, Brereton's suggestions about what a branded cinema should stand for are thoroughly embraceable even in a case of transnational cinema. In his opinion, a "branded film signals to the consumer the origin of the product, providing assurances about the place and methods of production. Ideally a brand signifies authenticity in all aspects of the production" 38 .

Besides the quality linked to the product, there are some other aspects equally important in branding: the brand recognition and the awareness of the brand among the (target) audiences.

All these aspects of branding cannot be fulfilled without a kenned plan, that's why a branded Baltic cinema is, in our opinion, only possible if there is a committee or a movement that sets up the guidelines and assesses production and stylistic choices of whoever takes part in the project. Something quite similar, but different in its ultimate - mainly stylistic purposes, happened with Dogma95, a collective movement that somebody matched with the idea of a branded product capable of reaching out to an international market ${ }^{39}$.

At this point, we can try to outline an initial draft about the qualities that Baltic cinema should entail within a perspective of a branding operation addressed to an international audience.

1. Baltic Sea: a precise geographical reference should be given. The seaside is considered as a border or a fruitful area of opportunities, exploration and exchange. The inland is recognizable as part of a country close to the Baltic Sea.

2. Transitional: it should tell stories about a geopolitical changes, socioeconomic developments, and cultural challenges.

3. Generational: young protagonists and young generation's viewpoint are likely to be preferred.

4. Identity, grotesque, cultural diversity: the characters' identity might be juxtaposed with some other identities present in the territory or interacting with it, and possibly the conflict is solved with the

\footnotetext{
38 P. Brereton, 'Branding Irish Cinema: reflections upon celtic consumer society and social change in Dublin', Irish Marketing Review 20 (2, 2009), 27.

39 P. Schepelern, 'Film according to Dogma: Ground Rules, Obstacles and Liberations,' in Transnational Cinema in a Global North: Nordic Cinema in Transition, eds. A. K. Nestingen, and T. G. Elkington (Detroit: Wayne State University Press, 2005), 86.
} 
awareness of a cultural diversity. The representation of the characters can emphasize certain features (grotesque) but it shouldn't fall into stereotyping.

5. Sexuality can be explored with no censorship when it contributes to shape the psychology of an all-round character.

6. Despair, depression: "dark" feelings, sadness, psychological disorders, drinking and drug problems shouldn't be avoided as long as they are framed in their specific sociological context.

7. Reflection and engagement: the stories should avoid any interpretation that might be the result of a predictable common place. The film should demand a higher level of engagement from the viewers, inviting them to reflect.

8. Nostalgia, regression to the past: melancholia and positive feelings can shed a light on historical events, which usually represent and ideal situation that hopefully will be repeated in the future (pride, strength, unity against the difficulties, spirit of cooperation or comprehension and so forth).

9. Politics and freedom: Baltic cinema should be capable of depicting these two aspects without being afraid of contradictions or ideologies.

10. If possible, some peculiar filming and editing techniques are agreed upon and widely utilized.

\section{Conclusions and further suggestions}

In this paper we explored Baltic cinema as a form of transnational cinema. Firstly we sought an insight on its popularity on the internet general, among scholars and in reference to cultural events such as festivals. We compared our results to some other transnational cinema, finding out that the presence on the web is not prominent, that the academic interest around Baltic cinema is still low and that there is a quite balanced ratio between webpages dedicated to Baltic cinema and webpages dedicated to festivals in which Baltic cinema present is (see figures 4 and 5).

Our first conclusion is that there is a strong potential in the online promotion and presence of Baltic cinema in the cyberspace and that internet could be exploited in a more efficient manner to increase the awareness of this specific transnational form of art.

Afterword we focused on the ambiguities about a proper and accepted definition of Baltic cinema. We investigated its main characteristics, especially in terms of themes and aesthetics, comparing Baltic cinema again with some 

other relevant transnational realities. For the comparison we proceeded in two steps: first we identified strong oppositions and possibly incompatible features; then we concentrated on the most pertinent topics that are believed by many scholars and critics to be connatural to Baltic cinema. As a result, we gained a batch of elements that can be considered as the core of Baltic cinema. We eventually showed that Baltic cinema is not linked to specific countries or authors but arguably depends on these core elements we just mentioned, which have to occur with a reasonable frequency for a film to qualify as part of the Baltic paradigm.

In the final part of our paper we addressed the possibility of considering Baltic cinema as a brand and we came up with an early list of features that might be included in such a project. These features were formulated in a branding-oriented perspective, taking into account the basic rules of any branding activity - in a nutshell: qualities linked to a product. We pointed out that branding can never be a spontaneous activity, for it requires planning and must be supported by a promoting entity (a person, an organization, a group or movement). The qualities and the reflections listed in the previous paragraph should be therefore considered only within the framework of a branding activity and never takes as universally valid. Furthermore, it cannot be excluded that a set of other collateral activities ought to be implemented to promote the brand identity. A few examples of collateral activities might include: a communication plan, a campaign, a social media strategy, a strategic event planning and management (festivals, conventions, conferences, fairs, cultural debates...), cooperation between regional players in the same industry to exchange feedback and knowhow, synergy with other industries, institutions and companies based in the region that can benefit from a mutual agreement (tourism, other commercial brands, universities).

Further research should be done about ownership patterns of the film producers located and operating in the Baltic area in order to investigate whether more possibilities in terms of collaboration, entrepreneurial initiatives, investments, cross media possibilities or knowledge sharing are feasible. For example, the Estonian Exitfilm, the Finnish Edith film and the Latvian Aboom are film studios partly owned by the Danish Zentropa. Exploring the ownership patterns of the Baltic film studios might shed a new light on the possible implications on the content of the Baltic cinema. 
Finally, even some forms of alternative sponsorship might be sought and pursued, like product placement, if the product genuinely and proudly reflects an aspect typical of a Baltic industry.

We understand that some of these suggestions may sound a slightly forward or too close to the consumerist American models and practices. Perhaps this is true, but only in part. Possibly the model is excessively marketoriented for a cinema with artistic aspirations such as the Baltic cinema and some points might need to be polished or redefined. However, for the sake of clarity, we firmly discourage content-wise any emulation of Hollywood, because of the concrete risk to fall into that easy superficiality dismissed by somebody - not without a touch of disdain - as "the Hollywood treatment" 40. We better prompt to consider, instead, some profitable commercial and communication techniques from Hollywood that can be incorporated in the Baltic cinema without affecting its main qualities and artistic pursuit. After all, if the American effectiveness in promoting their idea of cinema was combined with the great potential of Baltic cinema, what can ever outdo the second one?

${ }^{40}$ Laaniste, 2011, 141. 


\section{References}

Anholt, S. Competitive identity: The new brand management for nations, cities and regions. Basingstoke [England]: Palgrave, Macmillan, 2006.

Anessi, T. 'Moving Ahead into the Past: Historical Contexts in Recent Polish Cinema'. IMAGES The International Journal of European Film, Performing Arts and Audiovisual Communication XI (20, 2012), 5-22.

Baltic cinema task force. In Wikipedia. Retrieved from http://en.wikipedia.org/w/index.php?title=Wikipedia:WikiProject_F ilm/Baltic_cinema_task_force\&oldid=236400137, 2008.

Bondebjerg, I., and Redvall, E. N. A Small Region in a Global World. Patterns in Scandinavian Film and TV Culture. Centre for Modern European Studies - CEMES, University of Copenhagen, 2011.

Branston, G., and Stafford, R. The media student's book, $4^{\text {th }}$ edition. New York: Routledge, 2006.

Branston, G., and Stafford, R. The media student's book, 5th edition. New York: Routledge, 2010.

Brereton, P. ‘Branding Irish Cinema: reflections upon celtic consumer society and social change in Dublin'. Irish Marketing Review 20 (2, 2009).

Google Webmasters [Googlewebmasterhelp]. How precise is the number of results in a site: query? [video file]. Retrieved from http://www.youtube.com/watch?v=2ix3mHeL7hg, September 21, 2010

Ingvoldstad, B. 'The Paradox of Lithuanian National Cinema.' Via Transversa: Lost Cinema of the Former Eastern Bloc, Place and Location: Studies in Environmental Aesthetics and Semiotics 7 (2008), 137-154.

Iordanova, D. Cinema of the other Europe: the industry and artistry of East Central European film. London, New York: Wallflower Press, 2003.

Kennedy, H. 'Tess - Polanski in Hardy Country'. American Film (October issue, 1979), 62-69.

Laaniste, M. 'Conflicting Visions: Estonia and Estonians as Presented in the Cinema of the 1990s and 2000s'. Studies on Art and Architecture, 20 (3-4, 2011), 124-143.

Ludewig, A. 'Screening the Beach-Probing the Past: The Baltic Sea in Contemporary German Cinema'. Landscapes: the Journal of the International Centre for Landscape and Language 2 (3, 2013), 2. Retrieved from http://ro.ecu.edu.au/landscapes/vol2/iss3/2 
Mazierska, E. 'Post-communist Estonian Cinema as Transnational Cinema'.

Kinokultura,

10.

Retrieved

from

http://www.kinokultura.com/specials/10/mazierska.shtml, 2010.

Menashe, L. 'Border crossings in the Baltic: The "Transit Zero" Film Conference'. Cinéaste 26 (3, 2010), 62-63.

Näripea, E. 'Nature, Movement, Liminality: Representing the Space of the Nation in 1960's Estonian Cinema'. Regionines Studijos (5, 2010), 89-107.

Niskanen, E., Kakeo, Y., Petkovic, S., and Severns, K. Japanese: Baltic Sea Region film co-production; Japanese views, No. 1228. ETLA discussion paper, 2010.

OECD. Education at a Glance 2013: OECD Indicators, OECD Publishing, 2013.

Paajanen, M., Kupi, O., Panfilo, A., and Urmas, J. 'International film cooperation inside the Baltic Sea Region and with Japan'. Aalto University Publication Series Business + Economy, 13, 2011.

Wallenberg, L. Bedroom Mazurka. In The cinema of Scandinavia. Ed. Soila, T., Wallflower Press, 2005, 161-169.

Schepelern, P. 'Film according to Dogma: Ground Rules, Obstacles and Liberations'. In Transnational Cinema in a Global North: Nordic Cinema in Transition. Eds. Nestingen, A. K., and Elkington. Detroit: T. G. Wayne State University Press, 2005, 73-107.

Schiller, H. I. (1997). 'Not yet the Post-Imperialist Era'. In The Media Studies Reader. Eds. O'Sullivan, T. and Jewkes, Y. London; New York: Arnold, 1997.

Sweden. CIA world factbook Retrieved from

https:// www.cia.gov/library/publications/the-worldfactbook/geos/sw.html, date accessed 2013, December 4

Vertovec, S. 'Conceiving and researching transnationalism'. Ethnic and racial studies, 22 (2, 1999), 447-462.

Weeks, H. 'Re-cognizing the post-Soviet condition: the documentary turn in contemporary art in the Baltic States'. Studies in Eastern European Cinema, 1 (1, 2010), 57-70. 